\title{
AOR
}

Selected Papers of \#AolR2020:

The $21^{\text {st }}$ Annual Conference of the

Association of Internet Researchers

Virtual Event / 27-31 October 2020

\section{RESEARCHING THE AMBIVALENT ROLE OF DIGITAL MEDIA IN ENABLING EDUCATIONAL PARTICIPATION OF YOUNG REFUGEES}

Michi S. Fujii

Faculty of Human Sciences, University of Cologne, Germany

Prof. Dr. Nadia Kutscher

Faculty of Human Sciences, University of Cologne, Germany

In 2015 an unprecedented number of young refugees came to Germany. Since their arrival, coping with the experience of forced migration and finding a place in a new country proves to be essential for their everyday life. Against this background, the question emerges, what role digital media do play in terms of benefits and risks when it comes to overcoming barriers in participation and education. So far, the relevance of digital media (and associated practices) for young refugees in formal (school), nonformal (youth welfare) and informal (leisure) educational contexts is scarcely investigated. Thus, the a) contradictory dynamics that are connected with digital media, b) different meanings of digital media in young people's lives in general and c) the dimension of vulnerability of this special target group, are researched in an ethnographical approach.

Digital media, such as smartphones, apps and learning tools, can be valuable in different spheres of (everyday) life and are discussed controversially regarding their potential for education (Erstad, 2012). Research on the issue of educational and digital inequality points to the relevance of social and cultural capital (Bourdieu, 1987) in the context of digital media use (Angus, 2007; Iske et al., 2008; Lareau, 2011; PausHasebrink et al., 2019). An interplay of educational disadvantages at the subject level as well as institutional structures at the context level is therefore assumed. Against this background, digital opportunities can be accompanied by risks of social and digital exclusion, potentially undermining educational participation and supporting social reproduction (Sefton-Green/Livingstone, 2020). Across all continents, there is an insufficient evidence base with regard to policy and practice of digital media in educational contexts (Livingstone et al., 2017). 
With reference to marginalized groups, such as young refugees and the potential of digital media, studies have shown the everyday relevance of digital media for refugees as an essential tool (Chamarkeh, 2013; Alam/Imran, 2015). While refugees face a range of restrictions in social participation in the receiving countries, e.g. regarding education, health care and access to labor and housing market (Kutscher, 2017), the question comes up, in what way digital media have a function for coping processes in this context. So far, first indications exist regarding the supportive role of mobile media for certain learning and appropriation processes (Gillespie et al., 2016; Kutscher/Kress, 2019) as well as for self-empowerment (Witteborn, 2015; Trujillo, 2018). At the same time, digital spaces are not detached from power and inequality relationships:

Resources and general conditions (e.g. socioeconomic status) decisively shape the use of digital media (in general: DiMaggio/Hargittai, 2001; Buckingham, 2007; Livingstone/Haddon, 2009; Paus-Hasebrink et al., 2019; in respect to refugees: Kutscher/Kress, 2018) and existing disadvantages persist respectively are being reproduced in digital spaces (see Ermel/Stüwe, 2019, 10). Marginalized groups also face greater risks concerning issues of privacy and surveillance (Gangadharan, 2017). In Europe, the evaluation of mobile phone data of refugees for identity verification is already in widespread use (Metcalfe/Dencik, 2019). In residential institutions, digital media can have conflicting meanings of support and control (Kutscher/Kress, 2015).

The joint research project of University of Cologne and Leuphana University Luneburg, funded by the German Federal Ministry of Education and Research, examines the question of the importance of digital media in the everyday life of young refugees for their educational participation using an ethnographic approach. Against the background of subjectively unequal conditions and the structural reproduction of digital inequalities as a challenge for digital educational contexts and activities, the research aims at identifying enabling and restricting conditions for participation of refugee youth in different educational arrangements. To avoid a "methodological localism" (Nieswand, 2008,78 ), the young people are being followed into their different everyday contexts in a multi-sited ethnography (Falzon, 2009), starting in the institutional settings of child and youth welfare institutions and schools. In a transorganisational perspective (Schröer, 2013) the practices of young refugees as well as of pedagogical staff and other actors in the different structures are reconstructed following a praxeological approach (Schatzki, 1996). The focus is on where and in what way - embedded in arranged pedagogical (in school, in tutoring, in youth welfare contexts) as well as informal practices (e.g. in the family, with peers, etc.) - educational and self-organized appropriation processes take place and digital media become relevant in overcoming or producing barriers to participation. Education is understood as a (partially medially moderated) transformative process (Bildung), which goes hand in hand with a change of world and selfrelationships and with the acquisition of orientation knowledge for coping with unknown situations (Jörissen/Marotzki, 2009) The methodological and methodical approach in the ethnography of the project identifies and analyzes both explicit and pedagogically planned as well as implicit and spontaneous practices with and in the context of digital media including participant observations in the sense of "follow-the-actor" in the respective everyday contexts of the young refugees, field discussions and interviews with different actors as well as artifact analyzes (Lueger/Froschauer, 2018) of the relevant digital media. Over 20 adolescents aged 12-24 years are participating during three ethnographic field phases. The data are interpreted according to the grounded 
theory methodology (Strauss/Corbin, 1996). Ethical questions of forced migration research (Kleist, 2015), such as participation in the research process and sensitivity for dealing with the limits of privacy, represent, in addition to the "dual imperative" of the application-oriented benefit of the research process for the participants (Unger, 2018), continuous reflective references for the research team in methodological and methodological terms.

\section{References}

Alam, K./Imran, S. (2015): The Digital Divide and Social Inclusion among Refugee Migrants. A Case in Regional Australia. Information Technology \& People, 28(2), 344365.

Angus, L. (2007): Implications for social inequality in internet use for educational policies and programs. In Kompetenzzentrum Informelle Bildung (eds.): Grenzenlose Cyberwelt? Wiesbaden, 15-29.

Bourdieu, P. (1987): Die feinen Unterschiede. Frankfurt a.M.

Buckingham, D. (2007): Digital Media Literacies: Rethinking Media Education in the Age of the Internet. Research in Comparative and International Education, 2(1), 43-55.

Chamarkeh, H. (2013): Social Media Usage, Tahriib (Migration), and Settlement among Somali Refugees in France. Refuge: Canada's Journal on Refugees, 29(1), 43-52.

DiMaggio, P./Hargittai, E. (2001): From the 'Digital Divide' to 'Digital Inequality': Studying Internet Use as Penetration Increases*. Working Paper Series \#15. Princeton University.

Ermel, N./Stüwe, G. (2019): Lehrbuch Soziale Arbeit und Digitalisierung. Weinheim.

Erstad, O. (2012): The learning lives of digital youth—beyond the formal and informal. Oxford Review of Education, 38(1), 25-43.

Falzon, M. (2009): Multi-Sited Ethnography. Theory, Praxis and Locality in Contemporary Research. London.

Gangadharan, S. P. (2017): The downside of digital inclusion: Expectations and experiences of privacy and surveillance among marginal Internet users. New Media \& Society, 19(4), 597-615.

Gillespie, M./Ampofo, L./Cheesman, M./Faith, B./liadou, E./lssa, A. et al. (2016): Mapping Refugee Media Journeys. https://www.open.ac.uk/ccig/sites/www.open.ac.uk.ccig/files/Mapping\%20Refugee\%20 Media\%20Journeys\%2016\%20May\%20FIN\%20MG_0.pdf 
Iske, S./Klein, A./Kutscher, N./Otto, H.-U. (2008): Young people's internet use and its significance for informal education and social participation. Technology, Pedagogy and Education, 17(2), 131-141.

Jörissen, B./Marotzki, W. (2009): Medienbildung - Eine Einführung. Stuttgart.

Kleist, J. O. (2015): Über Flucht forschen. PERIPHERIE - Politik • Ökonomie • Kultur, 35(138-139), 150-169.

Kutscher, N. (2017): Geflüchtete als Zielgruppe medienpädagogischer Arbeit in der digitalisierten Gesellschaft. In S. Eder/C. Mikat/A. Tillmann (eds.): Software takes command. München, 203-217.

Kutscher, N./Kreß, L.-M. (2018b): The Ambivalent Potentials of Social Media Use by Unaccompanied Minor Refugees. Social Media \& Society, 4(1): Special Issue "Forced Migrants and Digital Connectivity" (eds. K. Leurs/K. Smets), 1-10.

Kutscher, N./Kreß, L.-M. (2019): Das Smartphone als Schlüsselmedium Transnationale und lokale Teilhabe unbegleiteter geflüchteter Jugendlicher. Migration und Soziale Arbeit, 40(04), 325-330.

Lareau, A. (2011): Unequal Childhoods. Class, Race, and Family Life. Berkeley.

Livingstone, S./Haddon, L. (2009) (eds.): EU Kids Online: Final report. London.

Livingstone, S./Lemish, D./Lim, S. S./Bulger, M./Cabello, P./Claro, M. et al. (2017): Global Perspectives on Children's Digital Opportunities: An Emerging Research and Policy Agenda. Pediatrics, 140(2), 137-141.

Lueger, M./Froschauer, U. (2018): Artefaktanalyse. Wiesbaden.

Metcalfe, P./Dencik, L. (2019): The politics of big borders: Data (in)justice and the governance of refugees. First Monday, 24(4). https://firstmonday.org/ojs/index.php/fm/article/view/9934/7749

Nieswand, B. (2008): Ethnografie im Spannungsfeld von Lokalität und Sozialität. EthnoScripts: Zeitschrift für aktuelle ethnologische Studien, 10(2), 75-103.

Paus-Hasebrink, I./Kulterer, J./Sinner, P. (2019): Social Inequality, Childhood and the Media. Cham.

Schatzki, T. (1996): Social Practices. New York.

Sefton-Green, J./Livingstone, S. (2020): Connecting and disconnecting learning between home and school. Australian Educational Leader, 41(1), 42-44. 
Schröer, W. (2013): Entgrenzung, Übergänge, Bewältigung. In W. Schröer/B.

Stauber/A. Walther/L. Böhnisch/K. Lenz (eds.): Handbuch Übergänge. Weinheim/Basel, 64-79.

Strauss, A. L./Corbin, J. M. (1996): Grounded Theory. Weinheim.

Trujillo, L. (2018): Contextualizing Voice in Refugee Youth Research. Medienimpulse, 55(3). https://journals.univie.ac.at/index.php/mp/article/view/mi1127

Unger, H. von (2018): Ethische Reflexivität in der Fluchtforschung. Forum: Qualitative Sozialforschung, 19(3).

Witteborn, S. (2015): Becoming (Im)Perceptible: Forced Migrants and Virtual Practice. Journal of Refugee Studies, 28(3), 350-367. 